\title{
Correlation of Asthma with Ammonia Exposure and Other Risk Factors among Poultry Farmers
}

\author{
Arriz Akbar ${ }^{1 *}$, Dewi S Soemarko ${ }^{2}$, Faisal Yunus ${ }^{3}$ \\ ${ }^{1}$ Postgraduate Student of Occupational Medicine, Faculty of Medicine Universitas Indonesia \\ ${ }^{2}$ Department of Community Medicine, Faculty of Medicine Universitas Indonesia \\ ${ }^{3}$ Department of Pulmonology \& Respiratory, Persahabatan Hospital, Indonesia \\ *Corresponding address: Arriz Akbar \\ Email: arriz_dr@yahoo.com
}

\begin{abstract}
Objective: To determine the prevalence of asthma and its corelation with ammonia exposure among informal workers of poultry farmers. Method: This study design was a cross-sectional analytic to 69 respondents using questionnaires, field observation, physical examination, spirometry measurement, and peak flowmeter test to diagnose work-related asthma and measurement of ammonia level in air environment of farm. All variable were bivariate tested by using Chi-square test or Fischer test. The variables which have $p$ value $<0,25$ were included into multivariate analysis by using binary logistic regression.

Results: The prevalence of asthma in poultry farmers was $21,74 \%$. In bivariate analysis, there was a significant corelation between working periode $(\mathrm{p}=0,035$ with $\mathrm{OR}=7,00)$ and smoking habit $(\mathrm{p}=0,018$ with $\mathrm{OR}=5,603)$ with asthma. There was no significant corelation between age, sex, nutritional status, work location, education level and marital status with asthma. The result of measurement of ammonia level in the poultry farm enclosure on average is $2,329 \mathrm{ppm}$. Multivariate analysis was performed on several risk factors that fulfilled the requirement $\mathrm{p}$ $<0,25$ ie working periode, smoking habit, nutritional status, and work location. From the results of mutivariate found that workers with a history of smoking habits have the strongest corelation $\mathrm{p}=0,013$ with OR 17,305.

Conclusion: The prevalence of asthma in poultry farmers was $21,74 \%$. There was no significant corelation between ammonia exposure in the work environment with asthma. But there was a significant corelation between working periode and smoking habit with asthma.
\end{abstract}

Keywords: asthma, ammonia exposure, informal sector, poultry farmer.

\begin{abstract}
Abstrak
Tujuan: Menentukan prevalensi asma dan hubungannya dengan pajanan ammonia pada pekerja informal dibidang poultry. Metode: Penelitian ini menggunakan studi potong lintang terhadap 69 responden menggunakan kuesioner, observasi lapangan, pemeriksaan fisis, pengukuran spirometry dan peak flowmeter tes untuk mendiagnosis asma terkait pekerjaan dan mengukur kadar ammonia pada udara di lingkungan kerja. Analisis bivariat dilakukan dengan Chi-square test atau Fischer test. Variabel dengan nilai $p<0,25$ dimaksukan dalam tahapan analisis multivariat menggunakan binary logistic regression.

Hasil: Prevalensi asma pada poultry farmers sebesar 21,74\%. Pada uji bivariat diperoleh hubungan yang bermakna antara lama waktu kerja ( $p$ $=0,035$ dan $O R=7,00)$ dan kebiasaan merokok $(p=0,018$ with $O R=5,603)$ dengan kejadian asma. Tidak terdapat hubungan yang signifikan antara usia, jenis kelamin, status gizi, lokasi kerja, tingkat Pendidikan dan status perkawinan dengan kejadian asma. Hasil pengukuran ammonia berada pada rerata 2,329 ppm. Pada uji multivariat diketahui beberapa faktor risiko dengan nilai p <0,25 yaitu lama kerja, kebiasaan merokok, status gizi, dan lokasi kerja, dengan hasil menunjukkan pekerja dengan riwayat kebiasaan merokok memiliki hubungan yang sangat signifikan dengan kejadian asma $p=0,013$ with OR 17,305.

Kesimpulan: Prevalensi asma pada poultry farmers sebesar 21,74\%. Tidak terdapat hubungan yang bermakna antara pajanan ammonia di lingkungan kerja dengan kejadian asma. Namun terdapat hubungan yang bermakna antara kebiasaan merokok dengan tingginya risiko kejadian asma pada pekerja.

Kata kunci: asthma, ammonia exposure, informal sector, poultry farmer.
\end{abstract}




\section{Background}

All occupations are at risk of causing diseases caused by work or the work environment. The development of increased industrial activity will potentially be a source of pollution / exposure that can harm the health of workers and the environment. One of the most important sectors to meet human needs for affordable food for many people is poultry farming. The efect that can be generated from poultry farming to the work environment, is the smell and dust. The smell is sourced from a high ammonia content, which comes from a pile of chicken dirt that is still wet. Air contaminated with ammonia gas can cause respiratory problems such as shortness of breath due to bronchospasm, cough, pulmonary edema, bronchitis and pneumonia. ${ }^{1}$

Ammonia gas is a colorless gas, and gives a very strong smell. In the air, ammonia can last about a week. Ammonia gas is exposed through the respiratory tract and may cause strong irritation to the respiratory tract. Because of its irritation, this pollutant can stimulate the inflammation of the upper respiratory tract from the nose to the throat. Exposure to ammonia gas to some degree may cause impaired lung function and sensitivity of the sense of smell. ${ }^{1,2}$

The respiratory tract is one of the most exposed parts of exposure to inhaled chemicals and is widely present in the work environment, so anticipation is needed to avoid direct exposure. Most of the workers due to lack of knowledge, do not really understand the dangers of exposure found in the farm environment. Many poultry farmers rarely or do not use PPE, like a mask when working everyday. So that will increase their risk of lung disfunction, one of them is occupational asthma.

Occupational asthma is a disease characterized by impaired respiratory flow and bronchial hyperactivity occurring as a result of a situation in the work environment and does not occur in excitability outside the workplace. ${ }^{3,4}$

It has been known that more than 250 substances can cause work-related asthma. Exposure to inhaled particles in the workplace is one cause of the onset of occupational asthma. The severity of the disturbance depends on the intensity and duration of exposure to the inhaled material. Besides the particle size and concentration of substances in the air also determine the progression of respiratory disorders. ${ }^{5}$

So far, asthma research on poultry farmers is still very minimal in Indonesia. While many factors that can trigger asthma attacks were found in poultry farms. As it is known that diseases involving immune systems such as asthma can occur or develop at low dose exposures even under threshold values, it is therefore necessary to conduct research to assess (1) What is the prevalence of asthma in poultry farmers?; (2) How much ammonia levels are found in the poultry farm environment?; and (3) Is there a corelation between ammonia levels with asthma in poultry farms?

\section{Methods}

The design of this study was cross sectional and it's located at Desa Pulau Harapan Banyuasin South Sumatra between January and Mei 2017. Data analysis was using chi square test for respondent characteristic, and multivariate analysis was using logistic regression test.

The population that can be examined is all informal industrial workers in the field of poultry farms in Desa Pulau Harapan Kecamatan Sembawa Banyuasin, South Sumatera. Sampling using total sampling technique, that is all poultry farms in Desa Pulau Harapan; all the farmers who fulfill the criteria of inclusion, exclusion and drop out criteria included into the research sample, except the farm or farmer who is not willing to participate in this research. The total number of farmer respondents is 116 people. Farmers who attended the data collection of 74 people, the remaining 42 people did not come because they are not willing to follow the research. Of 74 respondents who performed all the research procedures, five people were excluded (drop out) because the results of spirometry measurements could not be used, resulting in a total of 69 people who become respondent research.

Primary data were obtained from questionnaires, physical examination, anthropometry, air ammonia measurement, spirometry examination, and measurement of peak flow expiration by using peak flowmeter tool. Structured interviews on respondents using questionnaires from Pneumobile Project Indonesia. ${ }^{6}$ Measurements of air ammonia levels in poultry farms were carried out by Balai Teknik Kesehatan Kesehatan Lingkungan / BTKLPP Class I Palembang.

This study was conducted in several activities, first measuring the air ammonia level in the environment of the 
farm to determine the level of exposure in the workplace to be studied, then the measurement of lung function of the farmer, followed by the interview to get the data about the characteristics and risk factors of the respondents to their work. Interviews were conducted at the same time, with physical examination and spirometry measurements.

\section{Result}

Table 1 shows that of 69 subjects, there were fifteen poultry farmers $(21,74 \%)$ suffering from asthma (based on the Pneumobile Project Indonesia Questionnaire) and seven people $(10,15 \%)$ who had pulmonary restriction disorder (based on Spirometry Test). Of the fifteen people, ten people get the first asthma attack after working at the poultry farm, while five people have had an asthma attack before they work on the poultry farm. From spirometry who had lung restriction disorder, ranging from mild restriction to severe restriction, one farmer who suffers from severe restriction was a worker who has had previous pulmonary tuberculosis/ TB disease and has completed Anti Tuberculosis Drugs treatment.

After measurement of expiratory peak flow (APE) on fifteen workers with asthma, seven workers who got the first asthma while working and three workers who had previously had asthma showed APE > 15\%, meaning there were $10,15 \%$ of poultry farmers who suffer from occupational asthma, and $4,35 \%$ suffer from work-exacerbated asthma, which has been confirmed by APE examination.

Table 1. Prevalence of Asthma and Lung Function Disorders in Farmers

\begin{tabular}{llcc}
\hline & Characteristics & $\begin{array}{c}\text { Amount } \\
(\mathrm{n}=69)\end{array}$ & $\begin{array}{c}\text { Percentage } \\
(\%)\end{array}$ \\
\hline Asthma & & & \\
& Not Asthma & 54 & 78,26 \\
& Asthma & 15 & 21,74 \\
Spirometry & & & \\
Test & Normal & 62 & 89,85 \\
& Obstruction & - & - \\
& Restriction & 7 & 10,15 \\
\hline
\end{tabular}

Table 2. Distribution of Respondents by Risk Factors

\begin{tabular}{|c|c|c|}
\hline Risk Factors & Frequency & $\begin{array}{l}\text { Percentage } \\
\quad(\%)\end{array}$ \\
\hline \multicolumn{3}{|l|}{ Working Period } \\
\hline - $\quad \geq 2$ years & 50 & 72,5 \\
\hline - $\quad<2$ years & 19 & 27,5 \\
\hline \multicolumn{3}{|l|}{ Use of PPE } \\
\hline - Using & 17 & 24,6 \\
\hline - $\quad$ Not Using & 52 & 75,4 \\
\hline \multicolumn{3}{|l|}{ Smoking Habit } \\
\hline - Non Smokers & 27 & 39,1 \\
\hline - Mild Smokers & 8 & 11,6 \\
\hline - Moderate Smokers & 30 & 43,5 \\
\hline - $\quad$ Severe Smokers & 4 & 5,8 \\
\hline \multicolumn{3}{|l|}{ Nutritional Status } \\
\hline - $\quad$ Less & 10 & 14,5 \\
\hline - Normal & 49 & 71 \\
\hline - $\quad$ More & 4 & 5,8 \\
\hline - Obese & 6 & 8,7 \\
\hline \multicolumn{3}{|l|}{ Atopy History } \\
\hline - $\quad$ Yes & 22 & 31,9 \\
\hline - $\quad$ No & 47 & 68,1 \\
\hline \multicolumn{3}{|l|}{ Tribe } \\
\hline - Java & 38 & 55,1 \\
\hline - $\quad$ Sumatera & 31 & 44,9 \\
\hline \multicolumn{3}{|l|}{ Work Location } \\
\hline - In the Cage & 56 & 81,2 \\
\hline - Outside the Cage & 13 & 18,8 \\
\hline
\end{tabular}

From the distribution table of respondents according to risk factors above, we can see that many farmers who have worked for more than two years, and many farmers who do not use PPE when they work. Based on family history of atopy, fewer farmers have a history of asthma.

In addition, most farmers also have a habit of smoking, and they work more in the chicken cage where in the chicken cage there is a higher ammonia exposure when compared to outside the cage. Factors above can be a risk for farmers in poultry farms for the occurrence of asthma for workers. 
IJCOM 2021 November; 1(2):56-62

Table 3. The Corelation of Risk Factors With Asthma

\begin{tabular}{|c|c|c|c|c|c|c|}
\hline \multirow[t]{2}{*}{ Risk factors } & \multicolumn{2}{|c|}{ Asthma } & \multirow[t]{2}{*}{ OR } & \multicolumn{2}{|c|}{$95 \%$ CI } & \multirow[t]{2}{*}{$\mathrm{P}$} \\
\hline & Yes & No & & Lower & Upper & \\
\hline Age of Respondent & & & 1,45 & 0,469 & 4,721 & \\
\hline - $\quad \geq 33$ years & 7 & 20 & & & & 0,350 \\
\hline - $\quad<33$ years & 8 & 34 & & & & \\
\hline Education Level & & & 0,82 & 0,079 & 8,542 & \\
\hline - No school & 1 & 3 & & & & 0,634 \\
\hline - Ever school & 14 & 51 & & & & \\
\hline Sex & & & 1,66 & 0,326 & 8,481 & \\
\hline - Men & 13 & 43 & & & & 0,422 \\
\hline - Women & 2 & 11 & & & & \\
\hline Marital Status & & & 0,68 & 0,131 & 3,488 & \\
\hline - $\mathrm{No}$ & 2 & 10 & & & & 0,487 \\
\hline - $\quad$ Married & 13 & 44 & & & & \\
\hline Working Period & & & 7,00 & 0,852 & 57,517 & \\
\hline - $\quad \geq 2$ years & 14 & 36 & & & & $0,035^{*}$ \\
\hline - $\quad<2$ years & 1 & 18 & & & & \\
\hline Use of PPE & & & 0,57 & 0,164 & 1,996 & \\
\hline - $\quad$ Not using & 10 & 42 & & & & 0,286 \\
\hline - Using & 5 & 12 & & & & \\
\hline Smoking Habit & & & 5,60 & 1,152 & 27,256 & \\
\hline - Smokers & 13 & 29 & & & & $0,018^{*}$ \\
\hline - $\quad$ Not Smokers & 2 & 25 & & & & \\
\hline Nutritional Status & & & 2,91 & 0,700 & 12,092 & \\
\hline - Obese & 4 & 6 & & & & $0,137^{*}$ \\
\hline - Normal & 11 & 48 & & & & \\
\hline History of Atopy & & & 1,09 & 0,322 & 3,677 & \\
\hline - Yes & 5 & 17 & & & & 0,561 \\
\hline - $\quad$ No & 10 & 37 & & & & \\
\hline Tribe & & & 0,77 & 0,242 & 2,475 & \\
\hline - Java & 9 & 29 & & & & 0,447 \\
\hline - Sumatera & 6 & 25 & & & & \\
\hline Work Location & & & 4,00 & 0,476 & 33,585 & \\
\hline - In the Cage & 14 & 42 & & & & $0,162^{*}$ \\
\hline - Outside the Cage & 1 & 12 & & & & \\
\hline
\end{tabular}


From table 3, it was found that most of the variables did not have significant corelation with asthma with $\mathrm{p}<0,05$, but smoking habit and working period had significant corelation with asthma value $\mathrm{p}<0,05$. For nutritional status and work location because $p<0,25$, then the four risk factors will be multivariate analysis.
Multivariate analysis was performed using multiple logistic regression test using Backward RL $(\alpha$ 0,05 and 95\% CI). Furthermore, SPSS program will exclude one by one variable that has $\mathrm{p}$ value approaching 1 (one) until all the variables have $p$ value $<0,05$.

From the results of multivariate found that farmers

Table 4. Multivariate analysis using logistic regression model

\begin{tabular}{llllll}
\hline & Koef & $\mathrm{P}$ & OR adj & Lower & Upper \\
\hline Working Period & 1,936 & 0,083 & 6,933 & 0,777 & 61,891 \\
Nutritional Status & 2,077 & 0,078 & 7,983 & 0,792 & 80,490 \\
Smoking Habit & 2,742 & 0,017 & 15,512 & 1,646 & 146,208 \\
Work Location & 1,182 & 0.298 & 3,261 & 0,352 & 30,197 \\
Constant & $-6,261$ & 0,001 & 0,002 & & \\
\hline
\end{tabular}

Table 5. The final result of regression logistics analysis

\begin{tabular}{llllll}
\hline & Koef & P & OR adj & Lower & Upper \\
\hline Working Period & 1,971 & 0,076 & 7,178 & 0,813 & 63,368 \\
Nutritional Status & 2,111 & 0,071 & 8,259 & 0,837 & 81,552 \\
Smoking Habit & 2,851 & $0,013^{*}$ & 17,305 & 1,804 & 165,978 \\
Constant & $-5,367$ & 0,000 & 0,005 & & \\
\hline R Squar $=0,331$ &
\end{tabular}

R Square $=0,331$

with smoking habits have a strong corelation with asthma, $p=0,013$. Positive effect of 2,851 means that if farmers at the farm smoke then the possibility / their risk will become asthma to 17,305 times greater than non-smoker farmers.

The result of $R$ Square value in multivariate analysis was 0,331 . This value indicates that smoking history in poultry farmers is one of the determinant factors in triggering asthma is $33,1 \%$, and there are $100 \%-33,1 \%$ $=66,9 \%$ other factors than this variable that can cause asthma in farmers such as poultry dust, chicken feed, weather or anything else, which is not included in this research variable.

\section{Discussion}

This study started from a preliminary observation of complaints of shortness of breath with accompanied by the sound of wheezing that often found in workers who work in the poultry farms. So the researchers in this study tried to identify risk factors associated with asthma and lung function impairment in workers at poultry farms in Desa Pulau Harapan. The chemical gas exposure studied in this study is ambient air free ammonia levels contained in workplace.

In this research, 69 poultry farmers have been studied, and fifteen people have asthma and 54 people are not asthma, so the prevalence of asthma in poultry farm is $21,74 \%$.

When compared with some studies of asthma in workers in other industrial sectors, asthma prevalence ranges from $5-15 \% .{ }^{3}$ In this study seen greater prevalence is $21,74 \%$, because this value does not only show occupational asthma or asthma work-exacerbated, but also including not occupational asthma. If the occupational asthma obtained from the results of a questionnaire confirmed by expiratory peak flow measurement then the prevalence to $10,15 \%$.

The results of the measurement of spirometry were obtained by seven people $(10,15 \%)$ who had lung restriction disorder, ranging from mild restriction to severe restriction and 62 people $(89,85 \%)$ of poultry 
farmer of spirometry showed normal. For impaired lung function obstruction is not seen from spirometry measurements, this is made possible by several factors, such as at the time of spirometry measurements of farmers with asthma not having an asthma attack, or they have taken bronchodilator drugs or are still in mild degrees of asthma. Besides spirometry examination is also conducted outside the work environment free of exposure contained in the farm so that at the time of spirometry examination is not found obstructive lung function disorder in the farmer.

Measurements of ammonia levels were performed on three poultry farms located in Desa Pulau Harapan, and it was found that ammonia levels in all work sites examined in the poultry farming environment found that the average yield was $2,329 \mathrm{ppm}$, this value higher than the composition of ammonia (NH3) contained in the supposedly clean air of 0,006 ppm. The lowest ammonia levels were found in the warehouse area of $1,283 \mathrm{ppm}$, and the highest ammonia content was found in chicken cage with a content of 2,941 ppm. In the literature mentioned when in the free air there are levels of ammonia between $0,5-1,0 \mathrm{ppm}$, then the ammonia gas is smelled because of the characteristic smell of ammonia. ${ }^{1,2}$

From the data of the respondents, $81,2 \%$ or 56 farmers work in chicken cage unit with high ammonia exposure with average value ( $\mu>2 \mathrm{ppm})$. Of the fifteen farmers with asthma, fourteen worked in a chicken cage unit, only one asthmatic person worked outside the cage unit. But in statistical test showed no significant corelation between high ammonia exposure in chicken ( $\mathrm{p}=0,162)$.

Although there was no significant corelation between high ammonia levels in chicken cage and asthma in farmers, either outside the cage or in the cage, this did not negate the effect of ammonia on asthma. Because this is consistent with the theory that asthma triggered by ammonia is most likely due to immunological mechanisms, not non-immunological mechanisms that are latent (irritant material). In the UK, one-third of workers who work as paddy farmers, poultry farmers and lab workers have symptoms of asthma, which clinically follow after two years of continuous exposure and will be faster in people with a history of smoking and atopy. ${ }^{7}$ So workers who are exposed to ammonia continuously with a certain level and a certain time is possible sensitized immunological system so that cause the occurrence of asthma, as in poultry farmers.

In addition, high levels of ammonia in the working environment exceeds the provision of a threshold value $>25 \mathrm{ppm}$, will cause direct irritation of the respiratory tract and the eye. These symptoms are known as Irritant Induced Asthma or Reactive Airways Dysfunction Syndrome (RADS). RADS is defined as asthma arising within 24 hours after first exposure to high concentrations of irritant substances such as gas, and asthma that persists for at least three months. This is defined as asthma due to work without latent period, is the asthma that arises after exposure to highperformance workplace materials and not too related to immunological mechanisms. ${ }^{8,9}$

\section{Conclusion}

This is the first study in Indonesia to look for asthma prevalence in traditional poultry farmers. The results of this study showed that many asthma found in poultry farmers who need special attention from all parties.

Suggestions for traditional poultry entrepreneurs must provide PPE for their workers; And for the government through public health centers/ Puskesmas to conduct routine supervision of the poultry business in its area to implement the control of exposure impact which can disturb the workers' health and the environmental comfort of the surrounding community.

\section{References}

1. Arwood RHJ, Ward GG. Amonia Inhalation Trauma. Mei 1985; 25(5): 444-447.

2. Susiyanto M. Antisipasi PT. Pupuk Kaltim terhadap Kebocoran Amonia. [Tesis]. Semarang: Universitas Diponegoro; 2007.

3. Dalphin JC, et al. Prevalence of Asthma and Respiratory Symptoms in Dairy Farmers in the French Province of the Doubs. American Journal Respiratory Critical Care Medicine. 1998; 158: 1493-8.

4. Aditama TY. Asma Kerja dan Penyakit Paru Akibat Kerja. Pendidikan Kedokteran Berkelanjutan Ikatan Dokter Indonesia. 1997; 1(1):37-42.

5. Shofer S, Haus BM. Quality of Occupational History Assessments in Working Age Adults With Newly Diagnosed Asthma. Chest, 2006; 130: 455-62.

6. Alsagaff H, Mangunnegoro H. Nilai Normal Faal Paru Orang Indonesia Pada Usia Sekolah dan Pekerja Dewasa Berdasarkan Rekomendasi American Thoracic Society (ATS) 1987: Indonesian Pneumobile Project. Surabaya: Airlangga University Press; 1993. Hal 1-29. 


\section{IJCOM 2021 November;1(2):56-62}

7. Yeung MC, Malo JL. An Etiological Agents in Occupational Asthma. EurRespir Journal. 1994; 7: 346-71.

8. Yeung MC, Malo JL. Occupational Asthma. The New England
Journal of Medicine. 2007; 333(2): 107-12.

9. Sastre J, Vandenplas O. Pathogenesis of Occupational Asthma. EurRespir Journal. 2003; 22: 364-7 